\title{
LEAD AND CADMIUN CONCENTRATION IN CATFISH (Pangasius polyuronodon) OF THE LOWER PART OF SIAK RIVER
}

\author{
Husnah, Siswanta Kaban, and Makri \\ Research Institute for Inland (Waters) Fisheries, Mariana-Palembang \\ Received April 19-2010; Received in revised form May 19-2010; Accepted May 31-2010
}

\begin{abstract}
Siak River is one of four big rivers in Riau Province suffered from anthropogenic substances deriving from various human activities. The substances not only degrade the water quality but also influence aquatic organisms such as fish. The effect of this substances not only directly such as sudden mass mortality of fish but also indirectly through bioaccumulation and biomagnification in fish body which could increase the exposure to public health risks. Study on two heavy metals (lead and cadmium) concentration in fish gill, liver and muscle was conducted in the lower part of Siak River starting from Pelita Pantai to Siak Indrapura. It can be concluded that concentration of cadmium in fish gill in four sampling sites, Pelita Pantai, Maredan, Perawang, and Buatan was exceeded of the acceptable limits by the National Drug and Food Standards of Indonesia, more than $0.2 \mathrm{mg} / \mathrm{kg} \mathrm{dry}$ weight. The similar concentration was also recorded in the fish liver in Buatan site, and in fish muscle in Siak Indrapura site. To sustain the existence of some economical fish such as cat fish, broad study on heavy metal accumulation in fish organs and its effect on reproduction of the fish should be considered.
\end{abstract}

KEYWORDS: heavy metals, accumulation, catfish, Siak River

\section{INTRODUCTION}

Siak River, known as the deepest Indonesian river located in Riau Province, has been suffered from environmental degradation as a result of some economical activities such as land clearance for either palm oil plantation, agriculture or human settlement, chemical industries, water transportation, and domestic activities. Decreasing in and loss of natural habitat of aquatic organisms and living aquatic resources have been recorded along Siak River since 2003 (Anonymous, 2007). Mass mortality of fish was occurred frequently and it affected fish diversity and abundance. Decreasing in fish size and catch are also faced by the fishermen since 2003. The effect of anthropogenic substances resulted from such economical activities to fish not only occured in the short term through a sudden mass fish mortality, but it may be delayed to the long term effect through bioaccumulation and biomagnification of certain heavy metals and complex organic compound.

Heavy metals in the environment are brought about primarily by anthropogenic sources although heavy metals are a natural part of the environment and provide numerous benefits to society (Su et al., 2009). Most of the heavy metals that get deposited in most water bodies from urban waste waters, industrial discharges and agricultural runoff (Olojo et al., 2005), oil combustion, internal combustion engines, local point sources, and in direct deposition from air pollution (Su et al., 2009) which commonly found in Siak River.
Discharge of heavy metals into river or any aquatic environment can change both aquatic species diversity and ecosystems, due to their toxicity, and accumulative behavior (Weher, 2008), threat to the existence of organisms thriving in the area, to the ecological integrity of the habitat as these heavy metals may enter the food chains, persist in the environment, bioaccumulate and biomagnify and increase the exposure to public health risks (Su et al., 2009). Aquatic organisms such as fish and shell fish accumulate metals to concentrations many times higher than present in water (Williams \& Giesy, 1978; Jayakumar \& Paul, 2006; Al-Kahtani, 2009) or sediment (Weher, 2008); they can take up metals concentrated at different levels in their different body organs (Staniskiene et al., 2006; Weher, 2008) and its accumulation was dose, time, and species dependent (Olojo et al., 2005; Weher, 2008).

Cadmium and lead have no known essential role in living organisms but they are toxic at even low concentrations and accumulate most in fish tissue such as gill and liver, kidney and muscle (Weher, 2008, Vinodhini \& Narayanan, 2008; Naggar et al., 2009; Akan et al., 2009). These heavy metals are part of eight elements of heavy metals stated by the World Health Organization as well as the Food and Agriculture Organization of the United Nations state that obligatory to monitore in fish (Staniskiene et al., 2006). 
Pangasius polyuronodon, is one of economical fish commonly caught by fishermen in Siak River (Husnah et al., 2008). It is likely that this fish can tolerate to water pollution, and distributed from Muara Tapung to the tributary of Mandau River. Study by Husnah et al. (2008) recorded some abnormal to the external organs of this fish. Due to this fact study was undertaken to investigate the levels of heavy metal in three different tissues, gill, liver, and muscle, of catfish, Pangasius polyuronodon.

\section{MATERIALS AND METHODS}

\section{Study Sites}

Water drainage area of Siak River was divided into three parts; the upper, middle, and lower part. The upper part consisted of two sub-drainage areas; Tapung Kanan and Tapung Kiri. The middle part covered Mandau River sub-drainage area starting from Kuala Tapung to the tributary of Mandau River, while the lower part covered area from tributary of Mandau River to the mouth of Siak River (Bapedalda, 2006).

The area of the middle part of Siak River drainage area was approximately 291,985 ha, and its covered land area was dominated by rubber plantation, bushes, forest, oil palm plantation, mix plantation, open area, and small part of agriculture and waters body. Part of the open area was categorized as mining area.
The physiography of the middle part was constructed from alluvial, flat area with the slope was less than $3 \%$, and with high erosion rate. The average rainfall reached $2,168 \mathrm{~mm}$. The highest rainfall was occured from October to December, while the lowest one was occured from June to July.

In rainy season, concentration of heavy metal such as cadmium (Cd) in some area in the middle part of Siak River was in the range of 0.01-0.02 mg/L which was already out of acceptable limits for class I water stating by National Drug and food standards of Indonesia. Most of cadmium was derived from industrial waste or from mineral mining.

\section{Sampling}

Five individual of Pangasius polyuronodon samples with the approximately $20 \mathrm{~cm}$ length were collected from fishermen in each sampling sites, Pelita Pantai, Maredan, Perawang, Buatan II, and Siak Indrapura, located in the middle part of the Siak River drainage area on November 2009 (Figure 1). The tissue of three fish organs, gill liver, and muscle, from 5 fish individuals in each sampling site were composite, put into the pre-acidified plastic bottle and preserved with $70 \%$ alcohol solution. These samples were sent to the Research Center for Limnology of the Indonesian Institute of Science, and analyzed with Graphite furnace AAS.

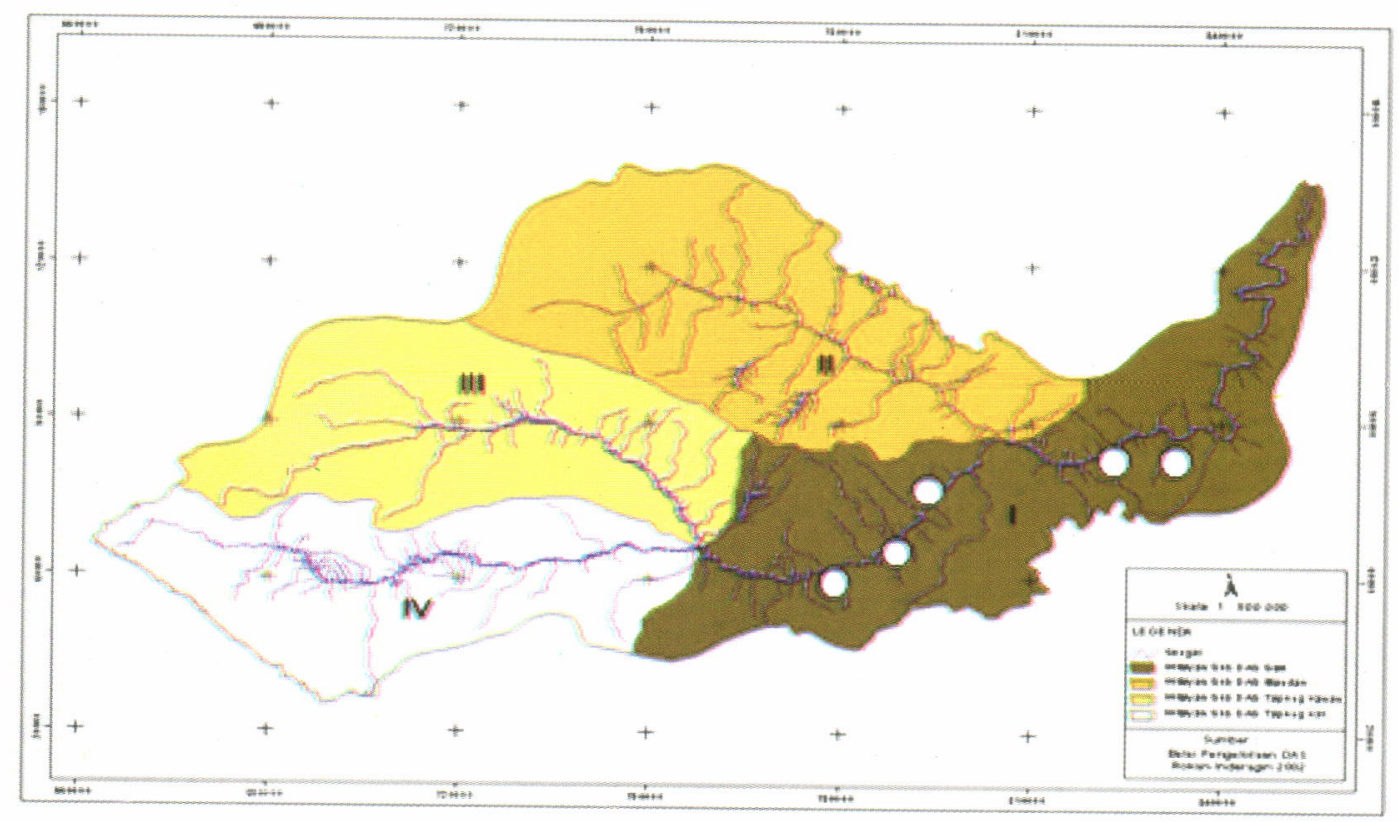

Figure 1. Study site. The lower part of Siak River starting from Tapung Kanan and Tapung Kiri River junction to Mandau River junction. Fish sample collection site (the white circle). 


\section{RESULTS AND DISCUSSION}

Accumulation of lead in three different tissue organs of Pangasius polyuronodon in 5 sampling sites varied. There was a pattern that accumulation of lead in the gill and muscle increased from Pelita Pantai to Maredan and started to decrease from Perawang to Siak Indrapura sampling site, while lead content in liver showed inversely (Figure 2). Higher concentration of lead in Pangasius polyuronodon gill in Pelita Pantai and Maredan than other sampling sites may relate to the closed distance of this sites to domestic and industrial sites such as tant farm and pulp and paper industry. Study conducted by Balzer et al. (2009) supported this finding that concentration of dissolved metal such as lead in the water tend to increase in this sampling sites and decreased close to Mandau River junction. Eventhough the concentration of dissolved lead in the water was low, in the range of 4$10 \mu \mathrm{g} / \mathrm{L}$, and categorized as unpolluted water, exposure of the fish to that concentration in the long run could magnify the concentration of lead uptake in the gill. Jayakumar \& Paul (2006); Al-Kahtani (2009) found that metal levels were significantly higher than the levels in water, indicating bioaccumulation.
Biaccumulation in the soft water such as Siak River (with the total hardness in the range of $9-17 \mathrm{mg} \mathrm{CaCO}_{3}$ / L) was faster than in hard water (Williams \& Giesy, 1978). Similar findings were reported by Buhler et al. (1977); Oladimeji et al. (1989) that concentrations of lead in the gills was higher than that in other fish organs. This phenomenon may be occurred because of their external location and necessarily intimate contact with the water (Olojo et al., 2005; Akan et al., 2009) that allows for dissolved or suspended materials in the water to be absorbed through the delicate epithelium. The lamella epithelial lining reacts to dissolved lead $(\mathrm{Pb})$ creating tissue osmoregulatory imbalance. The change in physiological property is evident in shrinkage observed at the lamella thus suggesting that lead $(\mathrm{Pb})$ intake mostly occurs via the gills. Prolonged exposure results in marked degeneracy of the epithelium followed by branchial arterial rupture, subsequently, ischemia (Olojo et al., 2005), hypertension and reproductive impairment (AlKahtani, 2009). There was no clear explanation for higher concentration of lead in the liver of Pangasius polyuronodon recorded in sampling sites located in the lower part (Buatan and Siak Indrapura) of Siak River.

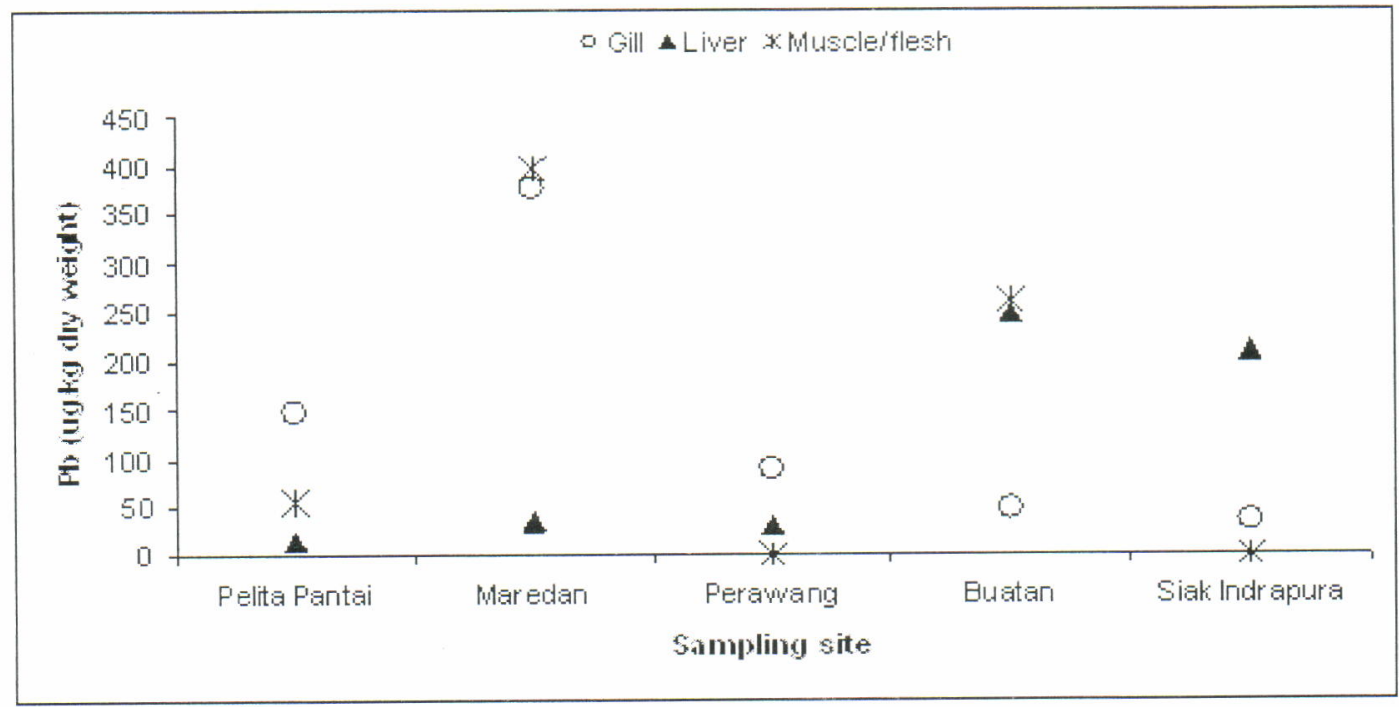

Figure 2. Lead $(\mathrm{Pb})$ accumulation in three tissue organs (gill, liver, and muscle) of Pangasius polyuronodon of the lower part of Siak River.

Concentration of lead in three organ tissues of Pangasius polyuronodon was below Food and Agriculture Organization limit which was $0.5 \mathrm{mg} / \mathrm{kg}$ wet weight (Nnaji et al., 2007). It was also supported by National Drug and Food Standards of Indonesia Regulation No.03725/B/SK/VII/89 that lead concentration in all fish organs studied was in acceptable limit for human consumption which was less than 2 ppm (Supriyanto et al., 2007).
Accumulation of cadmium in the gill and liver of Pangasius polyuronodon had a similar pattern with accumulation of lead in the gill and liver. Cadmium tended to increase from Pelita Pantai to Maredan sampling site and decrease to the lower stream to Siak Indrapura while it showed a reverse pattern in the liver (Figure 3). As already mention earlier, higher concentration of $\mathrm{Cd}$ in Pelita Pantai and Maredan sampling sites could relate to domestic and tant farm. Eventhough concentration of cadmium in the water 
less than $2 \mathrm{ug} / \mathrm{kg}$, (Balzer et al., 2009) and in the range of 0.1-0.02 mg/L (Badan Pengendalian Dampak Lingkungan Provinsi Riau, 2006), exposure of the fish in the long term could accumulate in the gill tissue to the concentration not allowable for human consumption both based on Food and Agriculture Organization and National Drug and Food Standards of Indonesia Regulation No.03725/B/SKNVII/89, which was $0.5 \mathrm{mg} / \mathrm{kg}$ wet weight and $0.02 \mathrm{mg} / \mathrm{kg}$ weigh wet.
According to Jayakumar \& Paul (2006), cadmium uptake was takirig place mainly through three routes namely, gills, skin, and aiso from food via the intestinal wall of freshwater fish. In addition, aquatic organisms were able to concentrate $\mathrm{Cd}$ in their tissue from very low water concentration (Jayakumar \& Paul, 2006; Williams \& Giesy, 1978; Al-Kahtani, 2009) and accumulation was faster from soft than hard water (Williams \& Giesy, 1978).

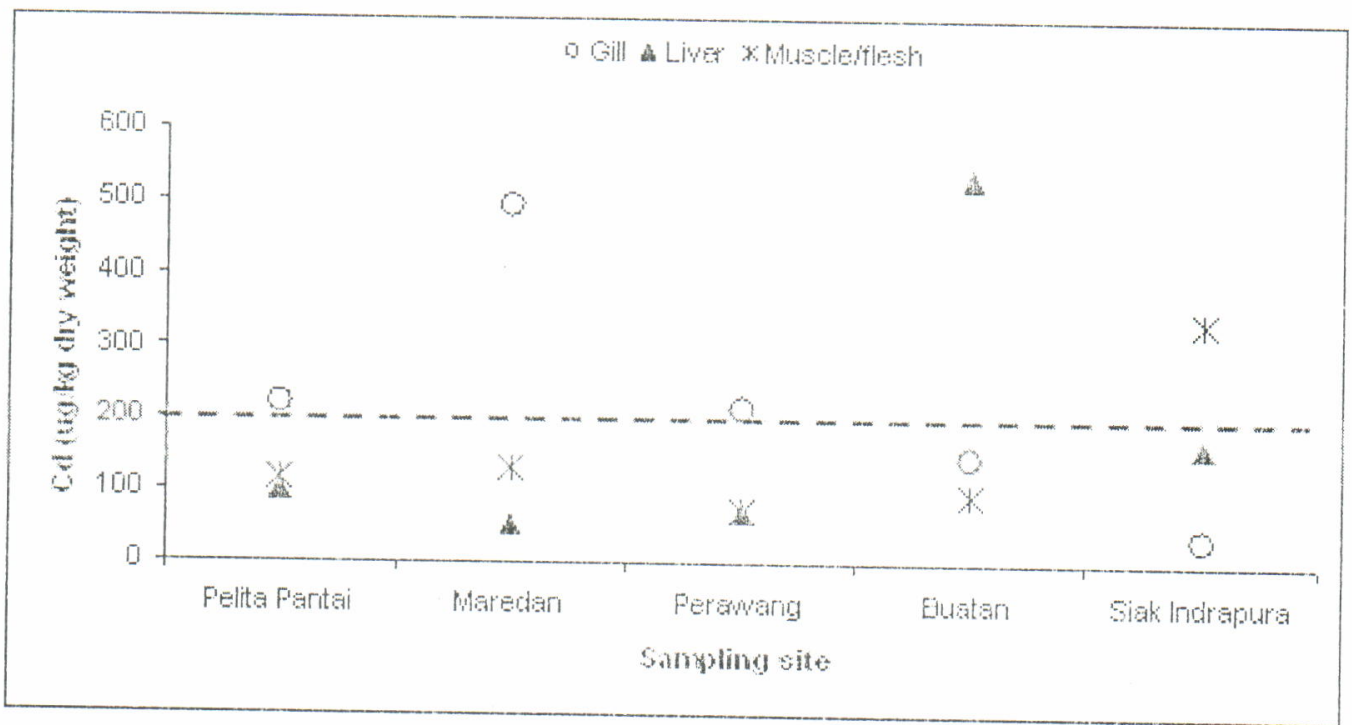

Figure 3.

Cadmium (Cd) accumulation in three tissue organs (gill, liver, and muscle) of Pangasius polyuronodon of the lower part of Siak River.

The effects of acute cadmium are high blood pressure, kidney damage, destruction of testicular tissue as well as destruction of red blood cells (Gupta \& Mathur, 1983 after Weher, 2008). Vinodhini \& Narayanan (2008) mentioned that accumulation of cadmiun lead to lesion, and damage on gill and liver.

\section{CONCLUSSIONS}

1. Out of two metals studied (lead and cadmium), concentration of cadmium in fish gill in four sampling sites in Siak River, Pelita Pantai, Maredan, Perawang, and Buatan was exceeded of acceptable limits by National Drug and food standards of Indonesia, more than $0.2 \mathrm{mg} / \mathrm{kg}$ dry weight

2. The similar concentration also recorded in the fish liver in Buatan site, and in fish muscle in Siak Indrapura site.

3. To sustain the existence of some economical fish such as cat fish, broad study on heavy metal accumulation in fish organs and its effect on reproduction of should be considered.

\section{ACKNOWLEDGMENT}

The authors are indebted to Ms. Melfa Marini and Mr. Agus Sudrajad for their assistance during the course of the study, and to the Director of the Research Institute for Inland Fisheries for giving opportunity to conduct the study. The study was supported by the research fund from the Ministry of Marine Affairs and Fisheries of Indonesia in 2009

\section{REFERENCES}

Anonymous. 2006. Laporan Akhir Konservasi Daerah Aliran Sungai Siak. Badan Pengendalian Dampak Lingkungan Pemerintah Provinsi Riau. 46 pp.

Anonymous. 2007. Akankah kasus Sungai Minamoto terulang. Dumai Pos Online. Senin, 02 Juli 2007.

Akan, J. C., F. I. Abdulrahman, O. A. Sodipo, \&. P. I. Akandu. 2009. Bioaccumulation of some heavy metals of six freshwater fishes caugh from lake chad in doron buhari, maiduguri, Borno state Nigeria. Journal of Applied Science in Environmentl Sanitation. 4 (2): 103-114. 
Al-Kahtani, M. A. 2009. Accumulation of heavy metals in tilapia fish (Oreochromis niloticus) from alKhadoud spring, Al-Hassa, SaudiArabia. American Journal of Applied Science. 6 (12): 2,024-2,029.

Buhler, D. R., R. M. Stokes, \& S. R. Coldwell. 1977. Tissue accumulation and enzymatic effects of hexavalent chromium in Rainbow Trout (Salmo gairdneri). Journal of Fisheries Research Board Canadian. 34: 9-18.

Balzer, W., K. Fische, I. Becker, J. Samiaji, \& C. Jose. 2009. Pollutant metal run-off from a tropical river system (Siak River, East Sumatera), their estuarine modification and coastal zone distribution. Paper presented in World Ocean Conference. Manado. 11-15 May 2009.

El-Naggar, A. M., S. A. Mahmoud, \& S. Tayal. 2009. Bioaccumulation of some heavy metals and histopatology alteration in liver of oreochromis niloticus in relation to water quality at different localities along the river nile, Egypt. World Journal of Fish and Marine Science. 1 (2): 105-114.

Husnah, E. Prianto, K. Fatah, S. Kaban, Makri, Mirna, \& Herman. 2008. Tingkat degradasi lingkungan perairan di Sungai Siak bagian hilir dengan benthic integrated biotic index. Laporan Tahunan/Akhir Riset pada Balai Riset Perikanan Perairan Umum. Pusat Riset Tangkap. Badan Riset Kelautan dan Perikanan. $62 \mathrm{pp}$.

Nnaji, J. C., A. Uzairu, G. F. S. Harrison, \& M. L. Balarabe. 2007. Evaluation of cadmium, chromium, copper, lead, and Zinc concentrations in the fish head/viscera of Oreochromis niloticus and synodontis schall of River Gaima, Zaria, Nigeria. Electronic Journal of Environmental, Agricultural, and Food Chemistry. 6 (10): 2,420-2,426.

Jayakumar, P. \& V. I. Paul. 2006. Patterns of cadmium accumulation in selected tissues of the catfish Clarias batrachus (linn) exposed to sublethal concentration of cadmium chloride. Veterinarski Arhiv. 76 (2): 167-177.
Oladimeji, A. A. \& B. O. Offem. 1989. Toxicity of lead to Clarias lazera, Oreochromis niloticus, Chironomus tantans, and Benacus sp. Water Air and Soil Pollution. 44: 191-201.

Olojo, E. A. A., K. B. Olurin, G. Mbaka, \& A. D. Oluwemimo. 2005. Histopatologi of the gill and liver tissue of the African catfish Clarias gariepinus exposed to lead. African Kournal of biotechnology. 4 (1): 117-122

Staniskiene, B., P. Matusevicius, R. Budreckiniene, \& K. A. Skibniewska. 2006. Distribution of heavy metals in tissue of freshwater fish in Lithuania. Polish. Journal of Environ. Stud. 15 (4): 585-591.

Supriyanto, C., Samin, \& Z. Kamal. 2007. Analisis cemaran logam berat $\mathrm{Pb}, \mathrm{Cu}$, dan $\mathrm{Cd}$ pada ikan air tawar dengan metode spektrometri nyala serapan atom (SSA). Prosiding Seminar Nasional III SDM Teknologi Nuklir. Yogyakarta. 21-22 Nopember 2007. 147-151.

Su, G. S., K. J. Martillano, T. P. Alcantara, E. Ragragio, J. de Jesús, A. Hallare, \& G. Ramos. 2009. Assessing heavy metals in the water, fish, and macroinvertebrate in Manila Bay, Philippines. Journal of Applied Sciences in Environmental Sanitation. 4 (3): 187-195.

Vinodhini, R. \& M. Narayanan. 2008. Bioaccumulation of heavy metals in organs of freshwater fish Cyprinus carpio (common carp). Int. Journal Environ. Sci. Tech. 5 (2): 179-182.

Williams, D. R. \& J. P. Giesy. 1978. Relative importance of food and water sources to cadmium uptake by gambusia affinis (Poeciliidae). Environmental Research. 16: 326-332.

Weher, S. M. 2008. Level of heavy metal Cd, Cu, and $\mathrm{Zn}$ in three fish species collected from the northen Jordan Valley, Jordan. Jordan Journal of Biological Science. 1 (1): 41-46. 
